\title{
Gender-Role Stereotypes: Perception of Tunisian Leaders
}

\author{
Hanen Khanchel ${ }^{1} \&$ Karim Ben Kahla ${ }^{2}$ \\ ${ }^{1}$ Institute of Advanced Business Studies, Carthage, Tunisia \\ ${ }^{2}$ High Business School, Campus of Manouba, 2010, Manouba, Tunisia \\ Correspondence : Karim Ben Kahla, High Business School, Campus of Manouba, 2010, Manouba, Tunisia
}

Received: November 2, 2018

Accepted: November 29, 2018

Online Published: December 3, 2018

doi:10.5430/bmr.v7n4p22

URL: https://doi.org/10.5430/bmr.v7n4p22

\begin{abstract}
The objective of this paper is to report on the problem of the glass ceiling in Tunisian companies. First, by recalling on the basis of statistical findings the situation of women at work, and then highlighting the main results of the surveys carried out in Tunisia on the question, and finally by highlighting some prospects for the strategies envisaged to go beyond The glass ceiling.

While organizations are places of meritocratic recognition in which more and more women graduate into skilled occupations, they are also places where informal, often unequal power relationships are built that determine access to decision-making positions. Women are becoming increasingly scarce as they rise in the hierarchy and remain a minority in high-level decision-making and accountability positions. They have less access to hierarchical positions (Ben Hassine, 2007). They are often limited to administrative or relational activities (Gadéa, 2003). Thus, in the private sector, out of 30 large Tunisian companies, only 4 of them have a woman on their works council (GIZ, 2013).

The identification of the different factors involved in the glass ceiling also raises questions about the behaviors and strategies developed in the context of organizational contexts reproducing the male career model, as well as the diversity of these behaviors. This study also allows us to consider changes and strategies of change in career development and women's access to decision-making positions that will push the boundaries.
\end{abstract}

Keywords: leadership, gender, stereotypes, glass ceiling, Tunisia

\section{Introduction}

For nearly four decades, gender equality reforms have been introduced around the world. However, despite the regulation that has been improved to ensure equal rights at work, major obstacles remain. Women remain discriminated against in terms of the jobs they have access to, the remuneration and benefits they receive. In addition, discrimination related to working conditions and access to positions of responsibility.

This problem remains recurrent when dealing with the situation of women executives in Tunisia. Indeed, the figure shows that there is a significant gap between men and women, whether in private or public companies. $0.76 \%$ of the female executive manager population (U.E., 2014). They have less access to hierarchical positions (Ben Hassine, 2007). They are often limited to administrative or relational activities (Gadéa, 2003). As for the private sector, out of 30 large Tunisian companies, only 4 of them have a woman on their works council (GIZ, 2013).

Glass ceiling, frontier effect, or lead sky (Marry and Jonas 2004), women always seem to encounter constraints that block the evolution of their professional trajectories and hinder access to positions of responsibility (Marchand, 2007). ). The research that we carried out in Tunisian companies focused on the phenomenon of the glass ceiling, but above all, on the durability of the discriminating factors that contribute to its edification. In this regard, we asked ourselves how we could explain the maintenance of this border effect in the professional trajectory of women executives, considering the evolution of societal valuesin terms of gender equality. To solve our problem, we first propose to present the relevant aspects, supported by surveys, which make it possible to determine our framework of research. Subsequently, we will draw a descriptive portrait of the presence of Tunisian executive women in the decision-making positions. Then we present the methodological axes underlying our investigation. Finally, we will present an overview of the result of our research. 


\section{The Literature Review of Glass Ceiling}

Several surveys have addressed the participation of women managers in the narrow circle of decision-making and difficulties they encounter in accessing it.

Our initial motivation is not limited to exposing an exhaustive literature review, but rather to present the relevant aspects, supported by surveys, that allow us to answer our research problem. To explain the concentration of women in the intermediate positions, studies indicate the phenomenon of "glass ceiling". The glass ceiling designates, according to Marchand and al (2007), the perceptible barriers or constraints that constrain the professional career development of women in the organizational hierarchy. More precisely, 'this' ceiling' of the professional profiles of women executives is due to 'invisible' factors, as indicated by the metaphor of the glass, which allows the gaze to pass and not the people, opening the perspective while blocking the movement (Marchand and al., 2007). The glass ceiling thus expresses, on the one hand, discriminatory attitudes that hamper women's professional development and, on the other hand, underlies the fact that inequalities are reinforced during the rise to positions of responsibility, Evoking the inclusion of this phenomenon on a set of gender inequalities and not as an isolated constraint that arises at some point in the course of a career path, which would misleadingly suggest that career models are linear systems.

\section{Tunisian Women's Access to Decision-Making Positions}

The hierarchical position in Tunisian companies remain the prerogative of men who continue to occupy, in a very high proportion (99.24\%), the most influential position of responsibility in the majority of the structure of companies (U.E., 2014). This situation is all singular when it is put in perspective with the change made by women in terms of access to higher education and the labor market. Women continue to be underrepresented in management (Marchand and al., 2007). Moreover, more we rise in the organizational pyramid, the fewer women are. There is a significant gap between men and women, whether in private or public companies.

\section{The Methodological Framework of Our Survey}

To explore the world of social representations and the perception of women executives, we opted for a qualitative approach and in this vision, individual semi-directive interviews were considered. The selected sample is composed of forty interviewees belonging to Tunisian companies. The method of interviewing was used to access the constructs and representations of the interlocutor. It provides an "background" of information and defines problems more thoroughly (Wacheux, 1996, p.15). We did an analysis of interpretive content, that is, taking into account not only the manifest content but also the latent content of the responses (Ahuvia, 2001).

\section{The Results of the Survey}

We will present below the results of our investigation and discuss them briefly. Our investigation has proved very fruitful, which will lead to a better interpretation of the symbolic field intrinsic to gender relations, in Tunisian enterprises. We have highlighted some revealing points, like the male-dominated cultural model and the discriminating factors of the glass ceiling.

\subsection{Perceptions of Leaders}

We find in discourses of leaders the stereotypes highlighted by Cornet and Bonnivert that seem strongly anchored in these coaches. The rhetoric of these consultants, which supports the development of their activities, finally seems to lead them into a dead end, or even into a trap. To promote feminine management and call for its development, they are led to affirm the existence of specifically feminine skills, and thus to help "lock up" women that they denounce elsewhere. In their work, Cornet and Bonnivert, in particular, tries to avoid this naturalization of male / female differences, but the text is regularly peppered with references to these stereotypes to support his thesis of the need to develop female leadership. Beyond that, the leadership she offers to women is based on staging and assertiveness and the development of a political stance. This amounts to suggesting the development of attitudes attributed to men. The discourse and the proposed solutions seem to irremediably turn around these stereotypes.

The majority of women interviewees believe that they work in a "men's universe". Indeed, women interviewed believe that they live in an unequal culture and that they are generally "unacceptable" as hierarchical superiors of the men of their structure.

They also claim that they have been at least once intimidated by male dominance. For Bourdieu (1998), "formal equality between men and women tends to conceal that, all other things being equal, women still occupy less favored positions". This gives rise to socially predetermined roles for women and men.

Nevertheless, for Landry (1990), the arrival of women in positions usually entrusted to men gives them more "visibility". Indeed, the fact of being in a position of male dominance creates several constraints, prescribes norms of 
conduct, more often implicit, not only to "be admitted" but also to climb the hierarchical scales. Interviewees are aware of this double injunction that affects women executives on all levels, they live with more or less disappointment. For example, they argue the need to prove their knowledge and credibility far more than men in the same job. Faced with this difficult situation, the interviewees expressed the determination with which they organized their work meetings and the perfection of their tasks carried out in order to avoid being criticized by men.

As for the assertion that women managers are obliged to work with more perseverance than men to succeed in their jobs, some attribute this to the firmness with which they must proceed in order to carry out their task. Indeed, the women executives interviewed who succeeded in obtaining positions of responsibility consider that they sometimes end up behaving like men.

The graph below highlights the perception of male managers in Tunisian companies of female executives who are sometimes obliged to behave "masculine" in the hierarchy (see Figure 1).

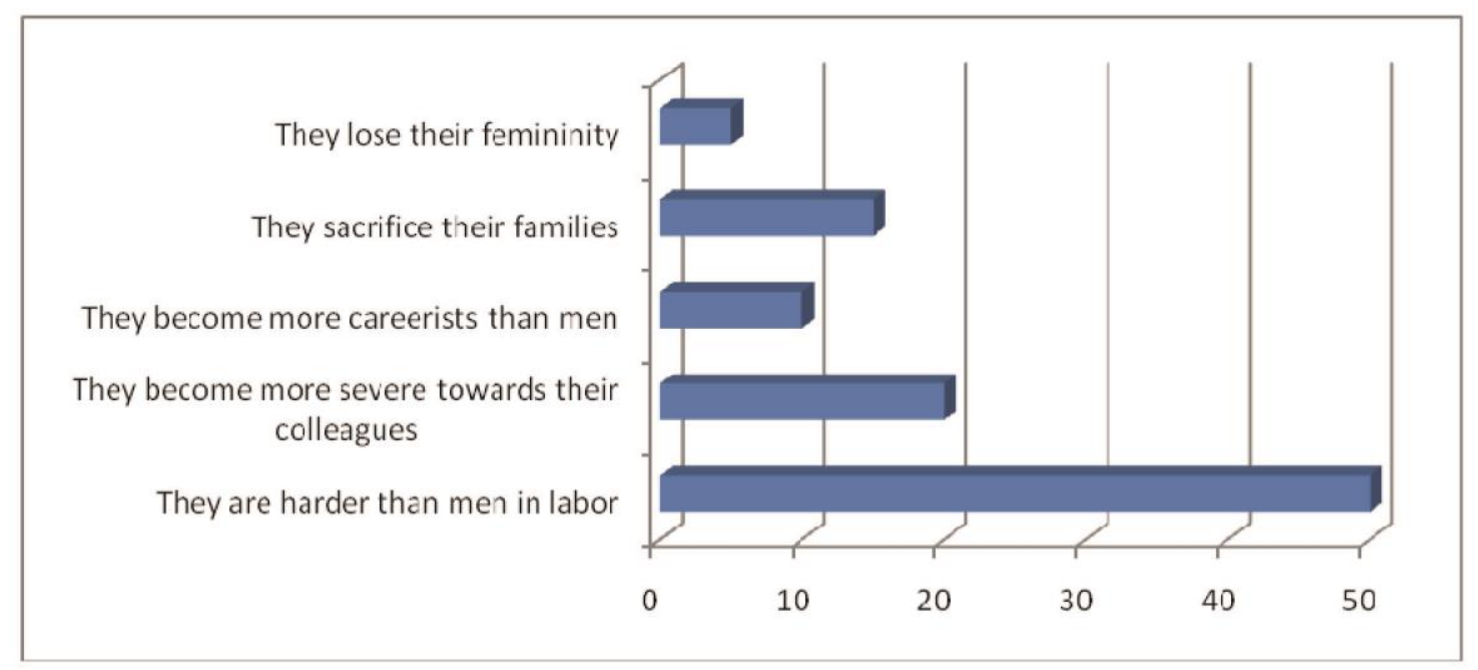

Figure 1. Perceptions of leaders of women in positions of responsibility

Concerning the perception of women, they believe that to promote the development of their careers, the strategies convert. Interviewees cited the importance of expanding social networks of influence and investing more in informal relationships. They consider that the personal qualities in which women excel more than men (relational qualities, diplomacy, rigor, perfectionism ...) constitute an alternative style of career management and should pay particular attention to it. Thus, as Landry (1988) showed by observing the emergence of leadership in small groups, women use, like men, strong and direct strategies of influence that are traditionally associated with the masculine gender (Duquette, 2007). 


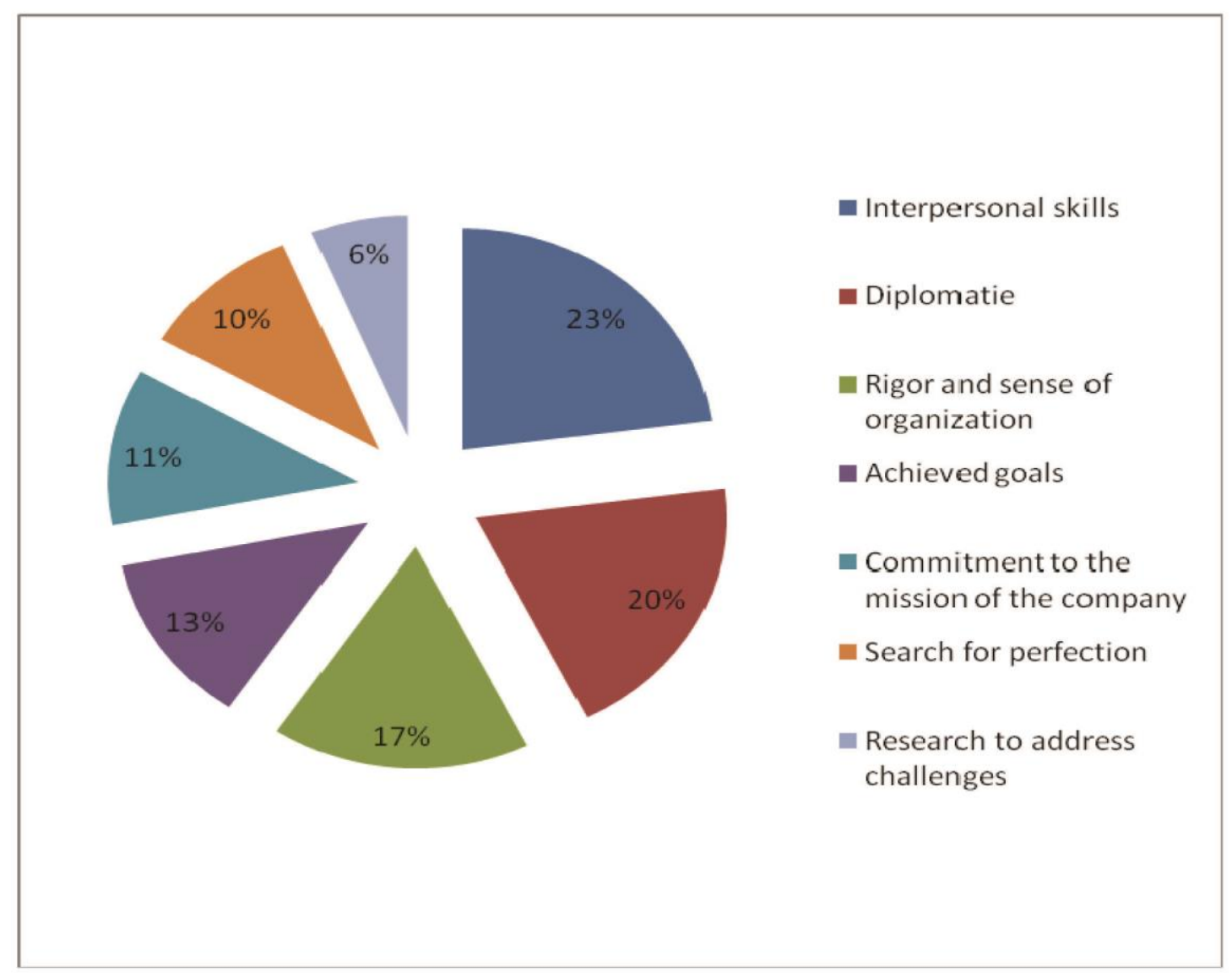

Figure 2. Characteristics of women in positions of responsibility

In this respect, Lips (2007) considers that women in positions of responsibility are confronted with a phenomenon of "double constraint". They have to face two stereotyped models: the model of the conciliatory, expressive, warm and kind woman and that of the ambitious, hard and confident leader. For Lips (2007), there is a contradiction between these two models since women can not be both feminine and powerful. Those with a behavior that is more focused on leadership qualities (rather masculine characteristics) will not be considered a real woman; And that showing too much feminine delicacy will be considered too soft and lacking the qualities of a true leader (Duquette, 2007).

\subsection{Glass Ceiling: The Discriminating Factors}

Several surveys confirm the hypothesis that women are more constrained in the environment considered traditionally masculine. More recently, Guedjali (2014), following a survey carried out in the academic world, pointed out that the administrative domain, where a bureaucratic system based on division of labor is established, forces the career development of Women.

This survey confirms the fact that women who advance in organizational functions are led to the periphery of strategic activities (Fortier, 2002). In order to delineate more clearly the factor that lead to discriminatory bias within the organizational structure studied, we have grouped together four families of norms that contribute to the concentration of women interviewed at the bottom of the hierarchical scale. These factors are prioritized in four areas (see Figure 3): professional disengagement associated with work / family conflict (50\%); Gendered social representations and stereotypes (30\%); The least inclusion of women executive in social networks (15\%); The lack of recognition of the qualification of women executive and human resource strategy (5\%). 


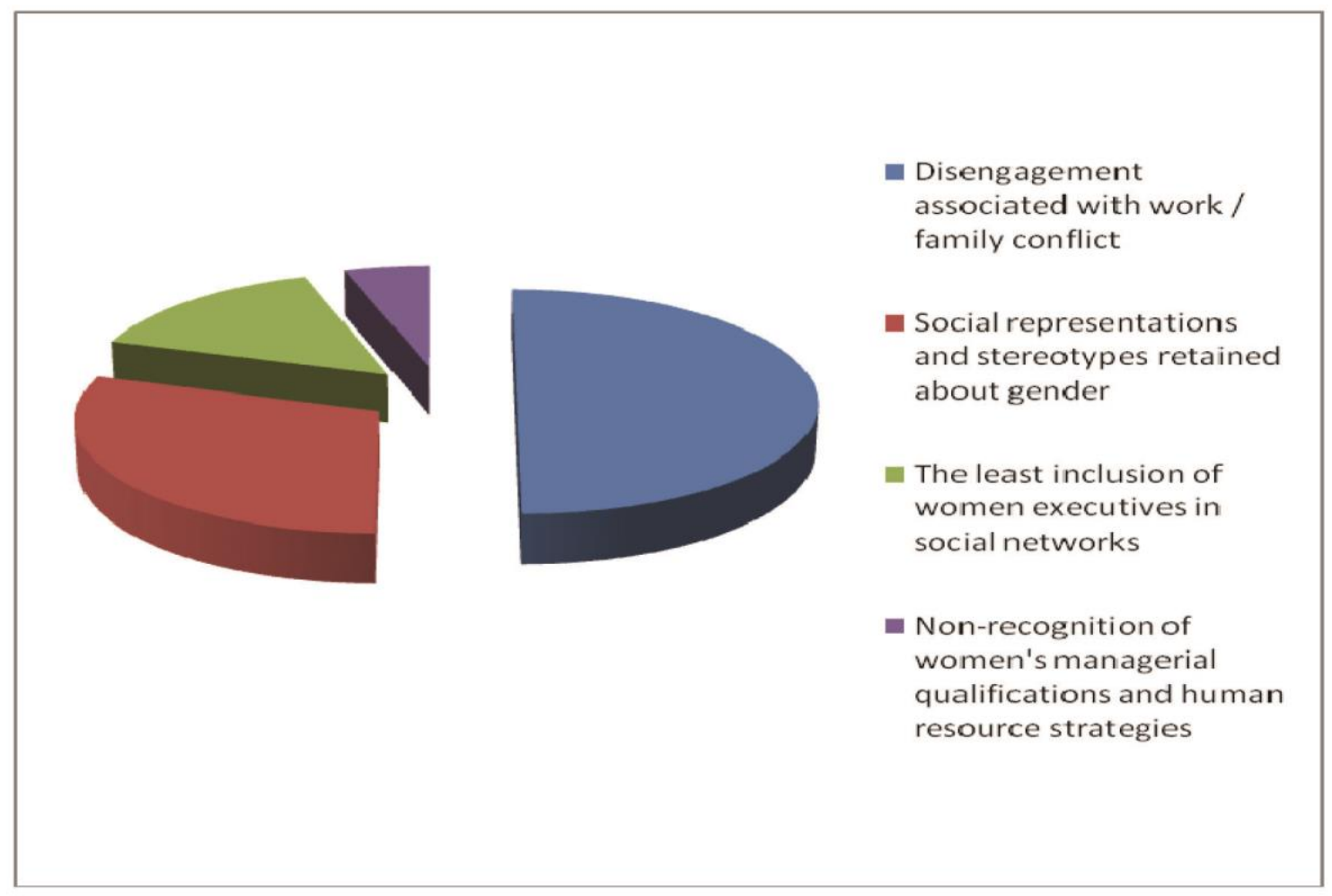

Figure 3. Glass ceiling discriminant factors

5.3 Gender Discrimination at Work and Access to Positions of Responsibility

Table 1. Responses of all participants $(\mathrm{N}=30)$ in propensity to gender discrimination and access to positions of responsibility.

\begin{tabular}{llll}
\hline & YES & NO \\
\hline 1. I would select a man in positions of responsibility, rather than a woman. & $\mathbf{6 0 \%}$ & $\mathbf{4 0 \%}$ \\
$\begin{array}{l}\text { 2. If I can't solve some task at work, I will rather ask for help from a man than a } \\
\text { woman. }\end{array}$ & $\mathbf{6 0 \%}$ & $\mathbf{4 0 \%}$ \\
\hline
\end{tabular}

Results from Table 1 show that about $60 \%$ respondents identify themselves primarily against the preferences for male candidates or employees in positions of responsibility, although it is better that a significant number of those respondents who would like for associates to important matters at work just to be men. Those people are more than $60 \%$ of respondents. While the majority of respondents declare, therefore, against a particular gender preference in hiring or dealing with business tasks in the job, there is still a relatively significant number of respondents who are still prone to such preferences $(60 \%)$. The results indicate the existence of preferences for gender discrimination against women in professional spheres, which can then have inequities between women and men in the labour market.

Table 2. Responses of men and women $\left(\mathrm{N}_{\mathrm{men}}=15, \mathrm{~N}_{\text {women }}=15\right)$ in the propensity of gender discrimination

\begin{tabular}{|c|c|c|c|c|}
\hline & Gender & YES & NO & $\begin{array}{l}\chi^{2} \\
(*)\end{array}$ \\
\hline \multirow{2}{*}{$\begin{array}{l}\text { 1. I would select a man in positions of responsibility, rather } \\
\text { than a woman. }\end{array}$} & Man & $80 \%$ & $20 \%$ & \multirow{2}{*}{5} \\
\hline & Woman & $40 \%$ & $60 \%$ & \\
\hline \multirow{2}{*}{$\begin{array}{l}\text { 2. If I can't solve some task at work, I will rather ask for help } \\
\text { from a man than a woman. }\end{array}$} & Man & $80 \%$ & $20 \%$ & \multirow{2}{*}{5} \\
\hline & Woman & $40 \%$ & $60 \%$ & \\
\hline
\end{tabular}

$(*) \overline{p<0,05 \text { and Theoretical chi-square }=3.84}$ 
Table 2 shows descriptive analysis of data by gender. It has been shown that men and women when choosing associates in positions of responsibility significantly differ $\left(\chi^{2}=5 ; p<0,05\right)$. The men were more likely than women to choose "a man in positions of responsibility" rather than a woman". Here we see that $80 \%$ of men tends to it. At the same time women in general also expressed significantly less preferences to it (20\%), while the vast majority of women $(60 \%)$ did not inclined to prefer male colleagues in positions of responsibility. The results therefore indicate that men are more prone to gender discrimination than women, although is an interesting fact that almost $40 \%$ of women tends to prefer a male colleague in positions of responsibility.

In terms of the propensity toward "seeking help of peers at work", there is still more marked statistical difference between women and men $\left(\chi^{2}=5 ; \mathrm{p}<0,05\right)$. Here we see that $80 \%$ of men tends to it. At the same time women in general also expressed significantly less preferences to it (20\%), while the vast majority of women (60\%) did not inclined to prefer the help of male colleagues at work. The results therefore indicate that men are more prone to gender discrimination than women, although is an interesting fact that almost $40 \%$ of women tends to prefer a male co-workers on work.

\section{Conclusion}

We have found through this research that organizational culture cannot be tackled independently of the symbolic production of social gender relations. It highlights the fact that professional equality will only emerge from a change in attitudes about the legitimacy of women in power.

In this respect, the typical profile of women managers who have succeeded in their professional career is related to the stereotype and social representation of the male career model (Guillaume, 2007). Moreover, the studied population of female Tunisian executives with functional jobs avoids female behavior. Our results show that, in order to occupy decision-making positions, women managers must transpose the reproduced socialization of the male career model. Nevertheless, we consider that women are able to act on social relationships and, beyond the dominant schemes conveyed in career management circles, they are able to contribute to the (re) construction of masculinity and Femininity in their workplaces.

\section{References}

Ben Hassine, A. (2007). Parcours de femmes cadres dans l'administration publique tunisienne : des femmes (pas) comme les autres. Télescope, 13(4), 42-53.

Baudelot , C., Gollac, M. (1997). Le salaire du trentenaire : question d'âge ou de génération ?

Bourdieu, P. (1998). La domination masculine, Paris, Seuil, coll. Liber, 134.

Cornet, A. \& Bonnivert, S. (2008). Leadership et Genre, pp.125-137, in GRH et Genre, Les défis de l'égalité hommes-femmes, Ed. A.Cornet, J.Laufer et S.Belghiti-Mahut, Vuibert, 246.

Duquette, J., J. (2007). Les relations de pouvoir dans les groupes de travail composés majoritairement des femmes, Mémoire. Montréal (Québec, Canada), Université du Québec à Montréal, Maîtrise en communication.

Fortier, I. (2002). Pouvoir, compétence et féminité : expérience d'ingénieures en gestion. Recherches féministes, 15(1), 65-91. https://doi.org/10.7202/000771ar

Guedjali, A. (2014). Trajectoire des femmes cadres algériennes à l'épreuve du plafond de verre.

Guillaume, C., Pochic, S. (2007). La fabrication organisationnelle des dirigeants. Un regard sur le plafond de verre.

Gadéa, C. (2003). Les cadres en France : Une énigme sociologique, Paris, Belin.

Internationale Zusammenarbeit (GIZ) GmbH, Stratégie Genre de la GIZ : Rapport sur l'état d'avancement de la mise en œuvre dans la période de 04/2012 à 07/2013.

Le Feuvre, Bataille, P., Laura, M., et al. (2013). La visibilité du genre dans des revues de sociologie du travail, Comparaisons France et Grande-Bretagne (1987-2012).

Landry, S. (1990). De l'insertion des femmes dans les hautes sphères des organisations, dans Changement planifié et développement des organisations : Priorités actuelles et futures. 2e éd., t. 2. Sillery, Presses de l'Université du Québec : 121-156.

Lips, H. M. (2007). Masculinity \& Femininity: Myths \& Stereotypes in Sex and gender : an introduction, 6th Edition, Boston, Mc Graw Hill, p.1-53.

Marchand, I., Saint-Charles, J., Corbeil, C. (2007). L'ascension professionnelle et le plafond de verre dans les entreprises privées au Québec. 
Marry et Jonas. (2005). Chercheurs entre deux passions : l'exemple des biologistes. Travail, genre et sociétés, $\mathrm{n}^{\circ} 14$, novembre.

Mahut, S., B. (2004). Les déterminants de l'avancement hiérarchique des femmes cadres. Revue française de gestion, 2004/4 (no 151), p. 145-160.

Philippe, S. (2013). Le plafond de verre : les freins à la mobilité ascendante des femmes dans les entreprises.

Union Européenne, "Mission d'identification d'un programme de promotion de l'égalité homme femme en Tunisie", financé par l’Union européenne (2014), Profil Genre Tunisie. 